\title{
The imagined Africa of the West: a critical perspective on Western imaginations of Africa
}

\section{Rune Larsen \& Stig Jensen}

To cite this article: Rune Larsen \& Stig Jensen (2019): The imagined Africa of the West: a critical perspective on Western imaginations of Africa, Review of African Political Economy, DOI: $10.1080 / 03056244.2019 .1660155$

To link to this article: https://doi.org/10.1080/03056244.2019.1660155

\section{Published online: 18 Oct 2019.}

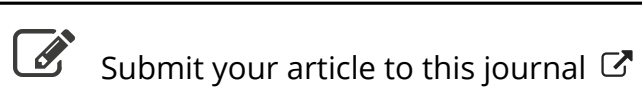

Цlll Article views: 1

Q View related articles ¿

View Crossmark data 


\title{
The imagined Africa of the West: a critical perspective on Western imaginations of Africa
}

Rune Larsen $\left(^{a, b}\right.$ and Stig Jensen ${ }^{c}$

anstitute for Anthropological Research in Africa, Faculty of Social Sciences, Katholieke Universiteit Leuven, Leuven, Belgium; ${ }^{\mathrm{b}}$ School of Culture and Society, Department of Anthropology, Aarhus University, Moesgård, Denmark; 'Centre of African Studies, Faculty of Theology, University of Copenhagen, Copenhagen, Denmark

\begin{abstract}
SUMMARY
This debate piece discusses how exceptionalised images of Africa are reproduced in contemporary Western discourse and imagination, and argues that these exceptionalised depictions of Africa enable Western consciousness to escape a confrontation with its own dysfunctionalities, hereby projecting all the excremental features characterising human existence on to its African Other. This is interpreted as a way for Western subjects to alter themselves into a position of idealised and imagined advanced civilisation - thus legitimising contemporary acts of neo-colonial exploitation in Africa.
\end{abstract}

\section{Introduction}

There are people in town man, crazy people in town

Eating bread and butter and honey, and drinking black coffee cola

They believe we are wild man, they believe we are wild

Just because we don't use any money, and we drink no coffee cola

But if you could go and see how they live

(Shame, shame)

Then, you discover how savage they are, so much wilder than we

(Song by Francis Bebey, African Electronic Music 1975-1982, LP/CD, Born Bad Records, 2011) $)^{1}$

Africanist scholarship has long discussed how Western imagination up to now has contributed to a construction of Africa as the world's universal Other - an umbrella term that will be unpacked throughout the piece (Ferguson 2006; Mbembe 2001; Mbembe and Nuttall 2004; Mudimbe 1988). ${ }^{2}$ One way Western discourse depicts Africa is as a romanticised 'primitive' entity bound to a past of harmonious engagements with 'nature' (Mudimbe 1988; Wainaina 2006). This is in opposition to the Western self-imagination as a collection 
of 'Modern' societies that 'differentiate absolutely between Nature and Culture, between Science and Society' (Latour 1993, 99).

However, this romanticised image of a primitive Africa is that of a 'jewel' of primitive and imagined naturalness that turns 'excremental' when it comes close (Žižek 2001, 63-69). ${ }^{3}$

This leads to a contrary but still problematic, simplistic and one-sided image of Africa being a disastrous place ravaged by interethnic warfare, natural disasters and disease epidemics (Wainaina 2006). While one cannot neglect the real aspects of this depiction, overemphasising the disastrous nature of the African continent, and neglecting the global influences evoking this state, lead to a false idea of Africans being passive subjects deprived of agency, without the capabilities of and/or interests in addressing their own problems, who therefore can be acted upon freely by external forces. These Eurocentric imageries of Africa reassemble what Mudimbe (1988) terms 'colonising structures' (5) that through manipulative ideological and theoretical efforts legitimise Western dominance in the African continent.

When discourses of Africa as an absolute entity deprived of agency emerge, the imagined characteristics of Africa also manifest into reality. However, the realness of the imaginary is completely distinct from the realness of a physical reality. Africa as an imagination of the West must therefore be understood as an 'irreality' (Sartre 2004), ${ }^{4}$ which is characterised solely by its imagined qualities. This renders it distinct from Africa as a cultural and geographic space. Despite only existing as an irreality, these images still influence the lived experience on the African continent. This is exemplified through 'the new scramble for Africa', where different Western and Eastern actors engage in an indirect recolonisation of the African continent, justified through discourses of socio-economic development and security (Carmody 2011). These interventions seem to be driven more by objectives of gaining global political power and material resources, and do not endure much resistance from the Western public.

However, when this new scramble is acknowledged by Western subjects, it is often projected as if its destructive aspects solely stem from the Eastern actors' (often embodied in the image of China) involvements (Sautman and Yan 2008). But does this Eastern Other not simply legitimise Western exploitation through the contradictory reasoning of: 'It wasn't me - it was also the Other'?

Throughout the piece we analyse exceptionalised imaginations of Africa, and argue that these serve to legitimise Western neo-colonial exploitation by allowing Western subjects to imagine themselves into positions of imagined and idealised advancement. The reason for this intervention stems from ongoing frustrations with the constant clashes between our academic and personal experiences in the African continent and the imaginations and depictions of Africa projected within several spheres of our Western surroundings including the academy. We hence found it imperative to address these acts of Othering and how they allow Western subjects to unconcernedly reproduce colonial exploitation in Africa. Presenting an analysis drawing largely on various philosophical perspectives in conversation with perspectives from disciplines such as anthropology, history and geography, we found it fruitful to bring this debate intervention to a critical and interdisciplinary platform. This is with the aim of encouraging a broader discussion on how we as scholars working with/in Africa can counter Africa's persistent imagined position as the absolute 
Other of the West - more than 40 years after Said (1978) published his work on Orientalism.

\section{Africa as the imagined Other}

Fanon (1967) sarcastically pointed out the irony behind imperial depictions of 'the North African' in late imperial France. Fanon shows how this character in psychiatric discourse was depicted as particularly insurgent, violent and promiscuous, and points to the paradoxes of this imagination. Consider his response to a suggestion made by a contemporary psychiatrist, Dr Mugniery, of not granting North Africans citizenship due to their 'primitive' behaviour of allegedly being prime users of French brothels, which Dr Mugniery suggests leads to an increased threat of rape:

Should we remind Dr. Mugniery that if the North Africans in France content themselves with prostitutes, it is because they find prostitutes here in the first place, and also because they do not find any Arab women (who might invade the nation)? (Fanon 1967, 12)

This is an identification of what characterises the Western depiction of its Other - that is, taking the West's own dysfunctionalities that manifest in its excremental complexes, and attaching these to the image of its Other.

\section{The corrupt Other}

When Africa in Western popular discourse is depicted as exceptionally corrupt, this also places the West in its opposition. This distracts public attention away from corrupt practices taking place inside the West. Take the numerous scandals of the former Italian prime minister Silvio Berlusconi or the corruption allegations against former French president Nicolas Sarkozy - paradoxically related to engagements with the former Libyan president Muammar Gaddafi (The Guardian 2018). Or the numerous corruption scandals against the Fédération Internationale de Football Association (FIFA), which cross-cut all continental lines (BBC News 2015; The Guardian 2017a, 2017b) - underlining the global nature of corruption, which cannot be exceptional to Africa. What is interesting is that Transparency International in 2018 ranked the European country of Bulgaria 77th out of 180 countries in their corruption index. Thus, Bulgaria ranks below several African countries, namely: South Africa and Morocco (73), Senegal (67), Sao Tome and Principe (64), Mauritius (56), Namibia (52), Rwanda (48), Cape Verde (45), Botswana (34) and the Seychelles (28) (Transparency International 2018)..$^{5}$ Of course, the scandals above do get criticised by people in the West. However, Africa still holds an exceptional discursive position as the continent of corruption. Smith (2007) describes his hesitation to engage with everyday experiences of corruption in Nigeria due to fear of reproducing Western misrepresentations: 'My effort to avoid portraying Nigeria's corruption as exotic, but also to sidestep confronting my own perverse enjoyment of that image, prevented me from addressing corruption head-on' (Smith 2007, xiii).

Smith shows how public conceptions of Africa being particularly corrupt installed in him an anxiety about addressing such issues, due to the risk of potentially reproducing misrepresentations of the continent. Hence, the Western reduction of Africa to a space of endemic corruption is a major hindrance to our ability to address the realness of corruption as experienced in particular African contexts. 


\section{The absurd Other}

In short, the Western image of Africa creates an imagined Other that defines the West in its impossible desire for imagined perfection and 'advancedness' (Mbembe 2001). Likewise, we have experienced public perceptions depicting Africans as exceptionally drawn towards spiritual beliefs and practices. This is followed by the idea that exceptional spirituality is a primitive feature that distinguishes Africa from the West. This is both false and manipulated, and one can argue that people in Western societies are just as believing as their African counterparts. In Kierkegaard's (1983) definition of a 'knight of faith', it is the non-reflective position from which the subject unconditionally trusts in the absurdities promised by its God - knowing that the God's promise is an absurdity in its impossibility - that constitutes an act of faith. Hence, when a consumer buys a cup of Starbucks coffee with the added surplus-value of 'creating better working conditions for Ethiopian coffee farmers ${ }^{6}$ - that is, the added value of imaginarily saving the world through consumerism (Žižek 2012) - is it not what Kierkegaard defines as an act of faith? Is it not to believe that one's God will deliver on a promise that one knows is too absurd to be possible? Is the present-day (Western) consumer not behaving like Kierkegaard's knight of faith in her/his insistence on creating a better world through destructive acts of mass consumerism? And if so, is it not both false and manipulative to imagine religious and spiritual reasoning and practice to be alien to present-day Western subjects, who themselves rely on 'the market' - an imaginary divine force - to solve the destructive consequences of their consumption and its global effects?

On the other hand, anthropologists have shown that African spiritual practices often are characterised by reflected negotiations between actors navigating different social contexts (Ashforth 1998; Schneider 2017). This is not exceptional to Africa, although it might seem more explicitly evident in light of the uncertain realities experienced by many people on the continent (Ashforth 1998). However, we are not saying that Western societies are exceptionally reliant on religious beliefs. We argue that the unconditional surrender to religious and spiritual beliefs, which by outsiders might be deemed 'irrational' and 'absurd', is in no way exceptional to Africa. Regardless, when Africa alone is granted the label of 'absurd spirituality and religiosity, ${ }^{7}$ it allows Western consciousness to position itself above these everyday absurdities, while maintaining its own absurd practices. Hence, Africa becomes a 'constitutive outside' (Laclau and Mouffe 1992) that embodies those behavioural features that the West denies practising. This brings consequences to the way Western actors approach issues within the African continent. Stillwaggon (2003) traces the Western exceptionalisations of African spirituality in relation to the African HIV/AIDS pandemic, and argues that Western scholarship often relies on a behavioural paradigm similar to that characterising the colonial racial sciences that stereotypically rendered Africans as genetically, culturally and socially distinct from Western subjects and societies. This misconception has been an obstacle to the prevention of the pandemic, and has legitimised a falsified exceptionalisation that positions Western subjects as less inclined to multiple sexual relations than their African counterparts (Ibid.) - echoing the earlier perspectives of Fanon (1967).

\section{The excremental Africa and its excessive 'jouissance'}

Another problematic aspect of the Western imagination of Africa is the idea of Africa being a disastrous, chaotic, violent and insurgent continent without political agency to 
counter these phenomena. However, Holston (2009) argues that insurgency can constitute enactments of alternative citizenships for actors marginalised within the present-day neoliberal spaces of the global South. Likewise, Fanon (1968) argues that violence, driven by strategic platforms, constitutes a necessity to reach a true anti-colonial transformation. Whereas Fanon's notion of violence being a revolutionary necessity has been criticised heavily (Arendt 1970), it still points towards the false idea that violence within Africa results from a lack of African initiative to counter social issues. Rather, violence must be interpreted as a reaction to the cultural and political context in which it emerges in the African case a context which is heavily shaped by external imaginations, interventions and structural violence following the continent's history of slavery, colonisation and now recolonisation. This reflection, which again is not exceptional to Africa, does not seem to present itself in the consciousness of many Western subjects. Instead, one finds theories within academic disciplines such as development economics that theorise African (under-)development without considering colonialism and its sedimented exploitative colonising structures. As noted by Rodney (1982), reflecting on Shaka Zulu's military advancement:

... Shaka took up many of the military and political techniques of Dingizwayo and greatly improved them. That is development. It is a matter of building upon what is inherited and advancing slowly, provided that no one comes to 'civilize' you. (Ibid., 133)

Rodney continues, emphasising that arguing for the benefits of African contacts with Europe in pre-colonial times is obscure:

It is clearly ridiculous to assert that contacts with Europe built or benefitted Africa in the precolonial period. Nor does it represent reality to suggest (as President Leopold Senghor once did) that the slave trade swept Africa like a bush fire, leaving nothing standing. The truth is that a developing Africa went into slave trading and European commercial relations as into a gale-force wind, which shipwrecked a few societies, set many others off course, and generally slowed down the rate of advance. (Ibid., 135)

But why is Africa depicted in a de-historicised manner, through which the continent's problems are projected as unsolvable and occurring outside of the global influences that run through its veins? Why is it that when we hear of conflicts, natural disasters and disease epidemics in Africa, these are always addressed as something to be contained within Africa, rather than being global issues? Can it be that an imagined Africa characterised by chaotic violence legitimises a present-day mission civilisatrice, whereby Western subjects can position themselves as saviours of the African continent? In a psychoanalytical sense this enables Westerners to imagine themselves within the position of the superego, and Africans as its opposite - the id (Freud 1968). Hence, the Westerner is positioned as the guardian of the ethical who, due to the West's imagined ethical superiority, can claim dominion over the African continent. This 'saviour complex' (for in-depth analysis and empirical exemplifications of this saviour complex, see Abu-Lughod 2002; Bandyopadhyay 2019; Bandyopadhyay and Patil 2017; Bex and Craps 2016) might be a reason why Western consciousness needs an imagined Africa, for what is the West outside its role as the self-proclaimed master of the ethical? - a role which Western actors, since the first missionaries arrived at African coasts, have cherished and rarely hesitated to position themselves within. 
Another reason is found in the Western discourse exceptionalising African disasters as threatening to Western societies. For instance, the Danish public service media enterprise Danmarks Radio (DR) projected that between 500,000 and 1.4 million West Africans would die from the Ebola epidemic of 2014-16, which struck the West African countries of Sierra Leone, Liberia, Guinea, Nigeria and Senegal (DR Nyheder 2014). This was out of proportion, and the Centers for Disease Control and Prevention's combined statistics show that in total 11,325 deaths could be traced directly back to the Ebola virus (CDC 2017). However, this has not prevented the same media house from making similar sensational depictions of the more recent Ebola outbreaks in Democratic Republic of Congo (DR Nyheder 2018). This to us illustrates how Africa is imagined to be so threatening that it must be kept at bay and contained within its imagined confines. This is equally exemplified through the debates within several European countries regarding the influx of African migrants crossing the Mediterranean Sea in order to seek a better life in their imagined Europe. One often finds a tendency of Western media solely focusing on the destructive consequences of this migration, without addressing the fundamental reasons behind such migration - which after all involves great risk, which is often well known to the migrants themselves (Plambech 2014) - and without addressing how migration between Africa and Europe is neither one-dimensional nor a new phenomenon. But who initiated this mass migration? The historical answer must be European explorers, colonialists and settlers of various kinds, whose penetration into the African continent accelerated from the beginning of the 16th century (Malowist 1992). Hence, if migratory connections between these two continents build on this colonial foundation, is it so odd that Africans experiencing the negative consequences of post-colonial recolonisation seek the pastures of what not only they, but also Europeans themselves, imagine as the land of 'civilised advancement'?

The tendency to imagine Africa as something to be contained can be understood as a construction of an Other to be sacrificed in order to imagine a larger community in light of the fundamental internal emptiness that characterises it (Esposito 2010). Thus, by projecting Africa as a chaotic space threatening the stability of the West, an imagined community is established through the 'immunisation' (Ibid.) of a structural Other, onto which all that causes uncertainty and fear can be transferred (Žižek 2008). However, in order for this Other to become more than a thought it must be made into reality (Appadurai 2006; Žižek 2008). This is the function of the mission civilisatrice, whereby enacting a saviour mission brings evidence to the constructed Other (through e.g. exceptionalising media representations [see above], donation campaigns for various 'humanitarian' causes, or volunteer tourism and the narcissistic peer-to-peer marketing that follows), which thus becomes a reality to Western subjects.

\section{Hating the Other to make oneself}

However, such a mission, although depicted as an act of love, might be a disguised act of hatred. For is it not an act of hatred to deprive an Other of its right to self-determination as a Subject, based on an universalised ideal of the ethical, a deprivation that is exemplified in the above-mentioned saviour complex? If we consider the present-day civilising mission as an act of hatred, we might be able to grasp why Western discourse imposes itself onto the representations of Africa. Consider Ahmed's (2014) perspectives on hate and its dialectic relation to narcissism: 
... in hating another, this subject is also loving itself; hate structures the emotional life of narcissism as a fantastic investment in the continuation of the image of the self in the faces that together make up the 'we'. (Ibid., 52)

Hence, this Western hatred of the African Other can be seen as a narcissistic act of creating a Western Self. Thus, in order to achieve the love of the West, and this will thus far only be the 'love' existing between a lord and a servant, Africa must become the physical manifestation of a Western imagination. Žižek (2001) argues that hatred towards Others stems from a fundamental envy of these Others' imagined excessive 'jouissance'. The West is imagined as civilised in its ability to control its fundamental desire for excessive jouissance, whereas the African continent is immunised from this civilised ability. To emphasise the absurdity of such an imagination one could examine Joseph Conrad's (1857-1924) novel Heart of darkness (1977 [1899]), which illustrates how self-imaginations of Westerners as particularly 'civilised', in practice are distorted, and how they - in their meeting with the Other - embody the savages they claim to civilise. This notion of the civilised revealing itself to be the actual savage equally resonates in the lyrics of the 'The coffee cola song' by Cameroonian artist Francis Bebey, cited at the beginning of this piece.

\section{Can the West imagine Africa in a representative way?}

We have established that the Western imagination of Africa can be interpreted as an act of envious hatred towards the Other. This drives a Western narcissism raised on a foundation of imagined civilised superiority. Likewise, such an imagination rests on Western subjects, ignorantly closing themselves off from the world by only adhering to their irreal disclosure of it, thereby reproducing Africa's position as an imagined Other. However, what remains is the question of how to counter this positioning.

According to Mbembe and Nuttall (2004) there are two ways of countering it. One way is to emphasise Africa's interconnectedness with the world. A second way is to take seriously the fact that Africa like, everywhere else, has its heres, its elsewheres, and its interstices (emplacement and displacement)' (Ibid., 351). These two strategies seem reasonable and aim to draw attention away from exceptionalised images of Africa, by placing Africa within the broader world. However, one feels compelled to ask: how are we to achieve this when nuanced perspectives challenging the West and its relations with the broader world, seem to be silenced for the reproduction of exeptionalised images? Garvey (1986) presents a radical suggestion:

Things that may not be true can be made so if you repeat them long and often enough. Therefore, always repeat statements that will give your race status and an advantage. That is how the white man has built up his system of superiority. He is always telling you he is superior and he has written history and literature to prove it. You must do the same. One of the great backgrounds for your argument which cannot be disputed is that you are older than any other man as a race because you are black. Your argument is that in nature everything by way of age darkens. Because you are darker than the rest of men, proves logically that you are older than the rest of men. Another proof of that is that even among white people they grow darker in skin as they grow older in age in a lifetime. (Ibid., 14)

Garvey's teaching is an early identification of the imagined superiority of the Western subject, which has survived into the present day. Interesting is the acknowledgement of discourse creating reality. This resonates in Heideggerian phenomenology, which argues 
for the centrality of language and discourse in the construction of a subject's ontological understanding of its 'being-in-the-world' (Heidegger 1962). With this we come closer to a way of achieving the two abstract strategies presented by Mbembe and Nuttall (2004). If we acknowledge that the imagined superiority of the West is constructed through means of discursively placing Africa within a position of inferiority, in order to cater for the narcissism of Western subjects, is the antidote not to emphasise the falsity of this imagination? Not through the Afro-romantic ideals presented by Garvey above - which indeed counters the Fanonian ideal of authentic anti-colonial struggle and violence ending in shared and equal humanity. Instead we must point out the obscurities when Africa and Africans are depicted exceptionally, which reduces the African continent to a static space outside of its interconnectedness with the world. This entails a degree of the counter-propaganda that Garvey advocates for in terms of emphasising the manipulative nature of imagining Africa in exceptional ways, and that enables Western subjects to avoid a confrontation with their own dysfunctionalities and excremental desires. Following Adichie (2009), we must therefore consciously deal with the 'dangers of a single story' that 'creates stereotypes. And the problem with stereotypes is not that they are [necessarily] untrue, but that they are incomplete. They make one story become the only story' (Ibid., 12:45), thereby robbing 'people of dignity. It makes our recognition of our equal humanity difficult. It emphasizes how we are different rather than how we are similar' (Ibid., 13:33).

Hence, in order to reposition Africa away from the perverted position as the imagined Other of the West, the African story is imperative to our analysis hereby recognising our equal humanity and ability to create knowledge. Not by simply exchanging Western thought for African, which leads to the creation of yet another single story. Instead we should include a broad range of perspectives (including [pan-]African thought) in our analysis and representation of Africa. This, in order to challenge a persistent tendency of silencing and closing off African perspectives - even within the analysis of African phenomena - and avoid an undesirable reversed dehumanisation that would keep us from confronting the imagined Other by making it real.

\section{Notes}

1. The permission granted by Francis Bebey's family and record label to publish the lyrics of the song is gratefully acknowledged.

2. In this piece, the terms 'West' and 'Africa' are used in a confrontational and decidedly reductionist manner to forcefully show the currency such tropes can gain.

3. Žižek (2001) describes this excremental complex as follows:

... with humans, the disposal of shit becomes a problem: not because it has a bad smell, but because it came out from our innermost selves. We are ashamed of shit because, in it, we expose/externalize our innermost intimacy. Animals do not have a problem with it because they do not have an 'interior' like humans [...] It comes from inside the body, and this inside is evil, criminal: The Inner of the body is very criminal. (59)

4. Sartre (2004) defines the realness of the imaginary as completely distinct from the realness of a physical reality. He therefore terms the reality of the imaginary the 'irreal'.

5. These rankings are of course dubious and tend to define corruption based on somewhat Eurocentric terms, hence also reproducing the problematic imagination of Western countries 
generally being less corrupt than the rest of the world. However, drawing on these rankings shows that Africa cannot be thought of as exceptionally corrupt - even when corruption is defined on a Eurocentric conception.

6. Thought experiment.

7. This is our own concept based on the analysis above.

8. In Lacanian terms 'jouissance' refers to enjoyment that goes beyond the mere principle of pleasure (Lacan 2014, 125).

\section{Acknowledgements}

We are grateful to Professor Emeritus Holger Bernt Hansen, Amanda Møller Rasmussen and Dr Luisa Schneider, and to the anonymous reviewer for their feedback on previous versions of this debate piece.

\section{Disclosure statement}

No potential conflict of interest was reported by the authors.

\section{Notes on contributors}

Rune Larsen is a Marie Skłodowska-Curie funded $\mathrm{PhD}$ researcher at KU Leuven's Institute for Anthropological Research in Africa and School of Culture and Society, Department of Anthropology, Aarhus University, Moesgård, Denmark. He holds an MA in African Studies from Copenhagen University. His academic interests revolve around political engagement and resistance in Southern Africa. He is currently working on a project focusing on youth, politics and social change in Windhoek, Namibia.

Stig Jensen is an Associate Professor at the Centre of African Studies, University of Copenhagen. He holds a $\mathrm{PhD}$ in Geography from Roskilde University. His research covers topics such as higher education and capacity building; political development and governance; conflict and security; and development aid, based on 15 years of research experience in Africa.

\section{ORCID}

Rune Larsen (1) http://orcid.org/0000-0003-4653-4465

\section{References}

Abu-Lughod, Lila. 2002. "Do Muslim Women Really Need Saving? Anthropological Reflections on Cultural Relativism and Its Others.” American Anthropologist 104 (3): 783-790. doi:10.1525/aa. 2002.104.3.783.

Adichie, Chimamanda Ngozi. 2009. “The Danger of a Single Story.” In TEDGlobal 2009: TED Conferences, LLC.

Ahmed, Sara. 2014. The Cultural Politics of Emotion. 2nd ed. Edinburgh: Edinburgh University Press.

Appadurai, Arjun. 2006. Fear of Small Numbers: An Essay on the Geography of Anger. Durham and London: Duke University Press.

Arendt, Hannah. 1970. On Violence. Orlando, Austin, New York, San Diego and London: A Harvest Book Harcourt Inc.

Ashforth, Adam. 1998. "Reflections on Spiritual Insecurity in a Modern African City (Soweto)." African Studies Review 41 (3): 39-67. doi:10.2307/525353. 
Bandyopadhyay, Ranjan. 2019. “Volunteer Tourism and 'The White Man's Burden': Globalization of Suffering, White Savior Complex, Religion and Modernity.” Journal of Sustainable Tourism 27 (3): 327-343. doi:10.1080/09669582.2019.1578361.

Bandyopadhyay, Ranjan, and Vrushali Patil. 2017. “'The White Woman's Burden' - The Racialized, Gendered Politics of Volunteer Tourism.” Tourism Geographies 19 (4): 644-657. doi:10.1080/ 14616688.2017.1298150.

BBC News. 2015. "Fifa Corruption Crisis: Key Questions Answered.” BBC News. Accessed January 22, 2019. https://www.bbc.com/news/world-europe-32897066.

Bex, Sean, and Stef Craps. 2016. "Humanitarianism, Testimony, and the White Savior Industrial Complex: What is the What Versus Kony 2012." Cultural Critique 92: 32-56. doi:10.1353/cul. 2016.0011.

Carmody, Pádraig. 2011. The New Scramble for Africa. Cambridge and Malden, MA: Polity Press. CDC (Centers for Disease Control and Prevention). 2017. "2014-2016 Ebola Outbreak in West Africa.” https://www.cdc.gov/vhf/ebola/history/2014-2016-outbreak/index.html.

Conrad, Joseph. 1977 [1899]. Heart of Darkness. New York: W. W. Norton and Company Inc.

DR Nyheder. 2014. "Nu er over 4.000 mennesker døde af ebola." DR Nyheder. Accessed January 7, 2019. https://www.dr.dk/nyheder/udland/nu-er-over-4000-mennesker-doede-af-ebola.

DR Nyheder. 2018. "Efter spredning til storby: Ebola udgør 'meget høj' sundhedsfare i DR Congo." DR Nyheder.

Esposito, Roberto. 2010. Communitas: The Origin and Destiny of Community. Translated by Timothy Campbell. Stanford, California: Stanford University Press

Fanon, Frantz. 1967. Toward the African Revolution: Political Essays. New York: Grove Press.

Fanon, Frantz. 1968. The Wretched of the Earth. New York: Grove Press.

Ferguson, James. 2006. Global Shadows: Africa in the Neoliberal World Order. Durham: Duke University Press.

Freud, Sigmund. 1968. The Ego and the Id and Other Works. London: Hogarth Press and the Institute of Psycho-Analysis.

Garvey, Marcus. 1986. Message to the People: The Course of African Philosophy. Massachusetts: The Majority Press.

Heidegger, Martin. 1962. Being and Time. Translated by J. Macquarrie and E. Robinson. Oxford: Blackwell Publishers.

Holston, James. 2009. "Insurgent Citizenship in an Era of Global Urban Peripheries." City \& Society 21 (2): 245-267. doi:10.1111/j.1548-744X.2009.01024.x.

Kierkegaard, Søren. 1983. Fear and Trembling/Repetition. Translated by Howard V. Hong and Edna H. Hong. Princeton, New Jersey: Princeton University Press.

Lacan, Jacques. 2014. The Seminar of Jacques Lacan Book X: Anxiety. Translated by A. R. Price. Cambridge and Malden, MA: Polity Press.

Laclau, Ernesto, and Chantal Mouffe. 1992. Hegemony and Socialist Strategy: Towards a Radical Democratic Politics. Repr. ed. London: Verso.

Latour, Bruno. 1993. We Have Never Been Modern. London: Prentice Hall.

Malowist, Marian. 1992. “The Struggle for International Trade and its Implications for Africa." In General History of Africa, Vol. V: Africa from the Sixteenth to the Eighteenth Century, edited by B.

A. Ogot. Paris; Berkeley, CA; London: Heinemann - University of California Press - UNESCO.

Mbembe, Achille. 2001. On the Postcolony. Berkeley, Los Angeles and London: University of California Press.

Mbembe, Achille, and Sarah Nuttall. 2004. "Writing the World from an African Metropolis." Public Culture 16 (3): 347-372. doi:10.1215/08992363-16-3-347.

Mudimbe, Valentin Yves. 1988. The Invention of Africa: Gnosis, Philosophy, and the Order of Knowledge. Bloomington: Indiana university press.

Plambech, Sine. 2014. "Becky's Journey." Documentary produced in Denmark and Nigeria. Copenhagen: Final Cut For Real ApS.

Rodney, Walter. 1982. How Europe Underdeveloped Africa. Washington, DC: Howard University Press.

Said, Edward W. 1978. Orientalism. New York, NY: Pantheon Books. 
Sartre, Jean-Paul. 2004. The Imaginary: Phenomenological Psychology of the Imagination. Translated by Jonathan Webber. London: Routledge.

Sautman, B., and H. Yan. 2008. "The Forest for the Trees: Trade, Investment and the China-inAfrica Discourse.” Pacific Affairs 81 (1): 9-29. doi:10.5509/20088119.

Schneider, Luisa T. 2017. "The Ogbanje who Wanted to Stay: The Occult, Belonging, Family and Therapy in Sierra Leone.” Ethnography 18 (2): 133-152. doi:10.1177/1466138116673381.

Smith, Daniel Jordan. 2007. A Culture of Corruption: Everyday Deception and Popular Discontent in Nigeria. Princeton: Princeton university press.

Stillwaggon, Eileen. 2003. "Racial Metaphors: Interpreting Sex and AIDS in Africa." Development and Change 34 (5): 809-832. doi:10.1111/j.1467-7660.2003.00330.x.

The Guardian. 2017a. "How the FBI Won 'The World Cup of Fraud' as Fifa Scandal Arrives in Court." The Guardian. Accessed January 27, 2019. https://www.theguardian.com/football/ 2017/nov/06/fifa-scandal-fbi-new-york-trial-chuck-blazer-sepp-blatter.

The Guardian. 2017b. "Fifa Corruption Trial Hears Allegations Officials Took Millions in Bribes." The Guardian. Accessed February 10, 2019. https:/www.theguardian.com/football/2017/nov/13/ fifa-corruption-trial-new-york-marin-napot-murga.

The Guardian. 2018. "Nicolas Sarkozy in Police Custody Over Gaddafi Allegations." The Guardian. Accessed February 7, 2019. https://www.theguardian.com/world/2018/mar/20/nicolas-sarkozypolice-custody-french-president-campaign-funding-libya.

Transparency International. 2018. Corruption Perceptions Index 2018.

Wainaina, Binyavanga. 2006. "How to Write About Africa." 19th January 2006. https:/granta.com/ how-to-write-about-africa/.

Žižek, Slavoj. 2001. On Belief. London: Routledge.

Žižek, Slavoj. 2008. The Sublime Object of Ideology. London \& New York: Verso.

Žižek, Slavoj. 2012. The Pervert's Guide to Ideology. Edited by Sophie Fiennes. New York: Zeitgeist Films. 